\title{
VOWEL ALTERNATION IN DISYLLABIC REDUPLICATIVES: AN AREAL DIMENSION
}

\author{
Shinji Ido \\ Aichi Prefectural University of Fine Arts and Music
}

\begin{abstract}
This paper analyzes a variety of languages with regard to vowel alternation patterns in their disyllabic sound symbolic reduplicatives (DSRs). The analysis reveals that (1) a number of different languages have their preferred patterns of vowel alternation for DSRs (e.g. /I/-/p/ in ding-dong and tick-tock in English) and (2) the relative height of each vowel against the other in a DSR is a linguistic feature that is primarily areal. The languages surveyed in this paper include Bukharan Tajik, Chinese, English, German, Kazakh, Korean, Manchu, Mongolian, Persian, Qarakhanid Turkic, Tatar, Tatar in Xinjiang, Turkish, Tuvan, Uyghur, Uzbek, and Uzbek in Xinjiang.
\end{abstract}

Keywords: reduplication, sound symbolism, vowel alternation, areal feature

\section{Introduction}

Many English sound symbolic reduplicatives are known to exhibit the vowel alternation patterns of $/ \mathrm{I} /-/ æ /$ and $/ \mathrm{I} /-/ \mathrm{p} /$ (e.g. in zig-zag and ding-dong) where the first vowel is higher than the second vowel (Reay 2006: 531). The data collected for this paper from a wide variety of languages evidence that a number of other languages also have their preferred patterns of vowel alternation for disyllabic sound symbolic reduplicatives (hereafter abbreviated as DSRs). For example, German DSRs, like English DSRs, show a clear preference towards 'high-low' vowel alternation - the vowel alternation where the vowel in the first syllable is higher than that in the second.

(1) German bim-bam, gick gack, klippklapp, piff paff, etc.

English and German are not isolated examples of languages that prefer a particular type of vowel alternation in their DSRs. DSRs in Turkish and several other major Turkic languages are no 
less consistent in their vowel alternation. A single prevalent type of vowel alternation in their DSRs is 'low-high', namely the vowel alternation where the vowel in the first syllable is lower than that in the second. Note that even fan-fin /fan fin/, which contains /a/ and /i/ and hence violates Turkish vowel harmony rules, is in conformity with the preferred low-high order:

(2) Kazakh

/baz buz, bal bul, zarq zurq, zalt zult, Salp zulp, qalt qult, sart surt, tars turs ${ }^{1}$, etc.

Tatar t taz t toz, t taz t foz, day doy, solt sílt, kæk kyk,

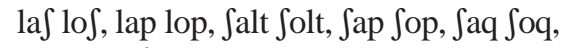
Jar Sor, tiq tuq, jalt jolt/, etc.

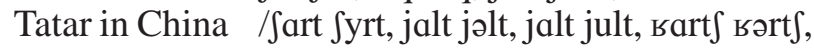
tars turs/, etc.

Turkish $\quad / t \int a k$ t $\int u k$, fan fin, paf puf, sap Jup, Jarp Surp, tak tuk/, etc.

Uyghur Ipar pur, Sar Sur, tan tuy, taq tuq, waz wuz, wal wul, tal tul, Sar Jur, Jaq Juq, talt tult/, etc. Uzbek /ьа ьи, ьаrs ьurs, falp Julp, ьart ьurt , taq tuq,jarq jurq, tars turs, qars qurs, вard3 burd $_{3}$, jalt jult, Jov Juv/, etc. ${ }^{2}$

The low-high vowel alternation in DSRs is not confined to the modern Turkic languages listed above. An analysis of sound symbolic words in Qarakhanid Turkic, an 11th Century Turkic language, also reveals the prevalence of particular types of vowel alternation in its DSRs; vowel alternations in the DSRs that appear in the Compendium of the Turkic Dialects (which is written in Qarakhanid) are limited to the following three types: $/\{\mathrm{a}, \mathrm{e}\} /-/$ $\{\mathrm{o}, \mathrm{u}, \mathrm{o}, \ddot{\mathrm{u}}\} /, /\{\mathrm{a}, \mathrm{e}\} /-/\{\mathrm{e}, 1, \mathrm{i}\} /$, and $/\{\overline{\mathrm{a}}, \overline{\mathrm{e}}\} /-/\{\overline{\mathrm{o}}, \overline{\mathrm{u}}, \mathrm{o}, \ddot{\mathrm{u}}\} /$, every one of which is of the 'low-high' type.

(3) Qarakhanid

çak çuk, çar çur, kar kur, tạ tuy, şal şul, çalk çulk, çart çurt, kart kurt, karç kurç, çā̆ $c ̧ \bar{u} \breve{\mathrm{g}}, k \bar{a} v k \bar{u} v, k \bar{a} \breve{\mathrm{g}} k \bar{u} \overline{\mathrm{g}}, k \bar{a} k k \bar{u} k, y \bar{a} b y \bar{u} b, y \bar{a} k$ $y \bar{u} k$, sart sirt

1 These are баж-буж, бал-бул, жарк-журк, жарт журт, жалп-жулп, калт-култ, сарт-сурт, and тарс-турс in Kazakh orthography.

$2 / \int \Lambda \mathrm{p} \int \mathrm{\gamma} /$ is the only DSR that appears in the list of sound symbolic words in Cheng, Shiliang and Abudureheman's (1987) grammar of Uzbek spoken in China. The vowel alternation in this DSR is also of the low-high type. 
In sum, all these modern and historical Turkic languages show a strong preference for the low-high vowel alternation in their DSRs.

This is remarkable, because in Inner Asia, the preference for the low-high vowel alternation in DSRs seems to be largely confined to the Turkic languages. Even DSRs in Mongolian and Manchu, which are often grouped together with the Turkic languages as Altaic languages, do not exhibit an exclusive preference for the low-high vowel alternation.

Mongolian and Manchu DSRs do not show any clear preference for the low-high vowel alternation. In fact, they have no clear preference regarding the relative heights of their alternating vowels. This lack of preference is manifestly exemplified by the presence of both /far far/ (low-high) and /f3r far/ (high-low) in the Manchu sound symbolic lexicon.

(4) Manchu

(Colloq.) /far far, f3r far, t t 1 p tşap/, etc. (Lit.) /

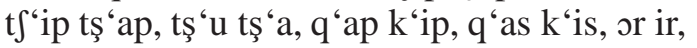
$p^{6} a^{6} p^{6} i k^{6}, t^{\prime} a p t^{\prime} i p, t^{6} a k^{6} t^{6} i k^{6}, t^{6}$ op t'ap/, etc.

Mongolian /poj paj, paj poj, pul pol, pujpaj, Jar Sir, Sar Sor, Sar Sor, Sir Sor, tur tar, tus tas, sar ser, tal tol, dedz dodz, dzig dzog, den don/, etc.

Given the lack of preference for the low-high vowel alternation in the DSRs of these two major Inner Asian languages, it seems unlikely that the consist preference for the low-high vowel alternation in the Turkic languages, most of which are spoken in Inner Asia, has emerged by chance. Do these data, then, suggest that vowel alternation in DSRs is a genetic feature? On the face of it, this observation seems plausible - after all, DSRs in all the Turkic languages the data from which are shown in (2) prefer the lowhigh vowel alternation. (DSRs in English and German, both of which are Germanic, also coincide with each other in their preference for the high-low vowel alternation pattern.)

However, an analysis of data from a wider variety of languages reveals that this observation is an oversimplification. The data that will be presented below allow the assumption that, synchronically speaking, the relative height of a vowel against the other in the DSR is a feature that is at least as areal as it is genetic. Admittedly, this assumption is highly speculative, not least because descriptive data of sound-symbolic words (let alone data 
of vowel alternation in DSRs) are hard to come by. However, there exists seemingly unequivocal evidence that supports this assumption. In the following paragraphs I present four pieces of such evidence.

\section{Evidence 1}

The single prevalent type of vowel alternation in DSRs in Korean, Chinese, and Vietnamese, which belong to different language groups but which are geographically close to one another, is high-low.
(5) Korean
kkung-kkwang, ppi-ppay, ssuk-ssak, thuk-thak, thung-thang, ttokttak, ttuk-ttak, ttwukttak, ttwukttek, $u$-a, $u$-wa, etc. ${ }^{3}$
Chinese bi-bo, di-da, ding-dang, ping-pang, pi-pa, $y i-y a$, etc.
Vietnamese ế-à, $g$ ổ-ghế, lê-la, rù-ró, tôi-tả, trúc-trắc, trục-trặc, tủm-tı̆m, etc.

\section{Evidence 2}

DSRs in Tuvan, a Turkic language, exhibit a lack of exclusive preference for the low-high vowel alternation. In other words, Tuvan DSRs do not share the preference for the low-high vowel alternation with DSRs in most major Turkic languages.

(6) Tuvan

$/ t^{\mathrm{h}}$ uy $\mathrm{t}^{\mathrm{h}}$ ay, $\mathrm{t}^{\mathrm{h}}$ og $\mathrm{t}^{\mathrm{h}} \mathrm{ug}, \mathrm{t}^{\mathrm{h}} \mathrm{ik} \mathrm{t}^{\mathrm{h}}$ ak, pim pom, purt part $/{ }^{4}$, etc.

This lack of preference for the low-high vowel alternation can be ascribed to the contact between Tuvan and Mongolian. Tuvan has been under a strong influence of Khalkha Mongolian

3 Vowel alternations in these Korean DSRs are of the types /i///a/, /i///e/, /o/-/a/, / $\mathrm{u} /-/ \mathrm{a} /, \mathrm{i} / \mathrm{/} / \mathrm{wa}$ /, and /u/-/a/.

4 These DSRs are spelt тын-тан, тог-туг, тик-так, бим-бом, and бурт-барт in Tuvan orthography. 
whose DSRs, like Tuvan DSRs, do not show any clear preference for the low-high order (or for the high-low order) (see (4)). ${ }^{5}$

\section{Evidence 3}

DSRs in Bukharan Tajik, a variety of Iranian that is heavily influenced by Uzbek, prefer the low-high vowel alternation.

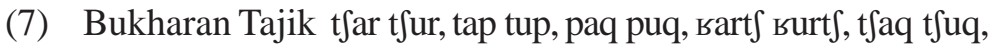
tfars tfurs, tars turs, Sap Jup, bay buy, xar xur, tfay tfuy, kar ker, tfart tfurt, taq tuq, qars qurs, kars kurs, ваз ьиз/, etc.

On the other hand, DSRs in Persian, another Iranian language, do not exhibit such a preference.

(8) Persian

dânb dunb, hây huy, rim râm, ðap ðâp, taq tuq, tik tâk, etc.

Though Persian and Bukharan Tajik are genetically very close to each other, only the latter exhibit a clear preference for the low-high vowel alternation in its DSRs. This preference could be ascribed to the intensive contact of Bukharan Tajik with Uzbek whose DSRs prefer the low-high vowel alternation (see (2)).

\section{Evidence 4}

DSRs in Hungarian (e.g. tik-tak, bim-bam, kip-kop, csitcsatt, and csip-csup) appear to prefer the high-low vowel alternation, which is the vowel alternation preferred by DSRs in other major European languages like German (see (1)) and English.

5 What all these data may imply is a gradation of preferred vowel alternation patterns in DSRs that spans across the Altaic languages. In the Far East, there is a language that prefers the high-low vowel order in its DSRs (Korean) whereas DSRs in the western members of the Altaic languages prefer the low-high order (Turkish, Tatar etc.). As for the languages in between them (Tuvan, Manchu, and Mongolian), they constitute a 'buffer' with both the high-low and low-high orders present in their DSRs. 


\section{Summary}

Thus, the data presented above point to the (synchronic) arealty of vowel alternation patterns in disyllabic sound-symbolic reduplicatives. ${ }^{6}$ The arealty is visible in (9) where languages that prefer the high-low vowel alternation, those that prefer the lowhigh vowel alternation, and those that lack any clear preference in their DSRs are indicated with $\uparrow, \downarrow$, and $\downarrow$, respectively.

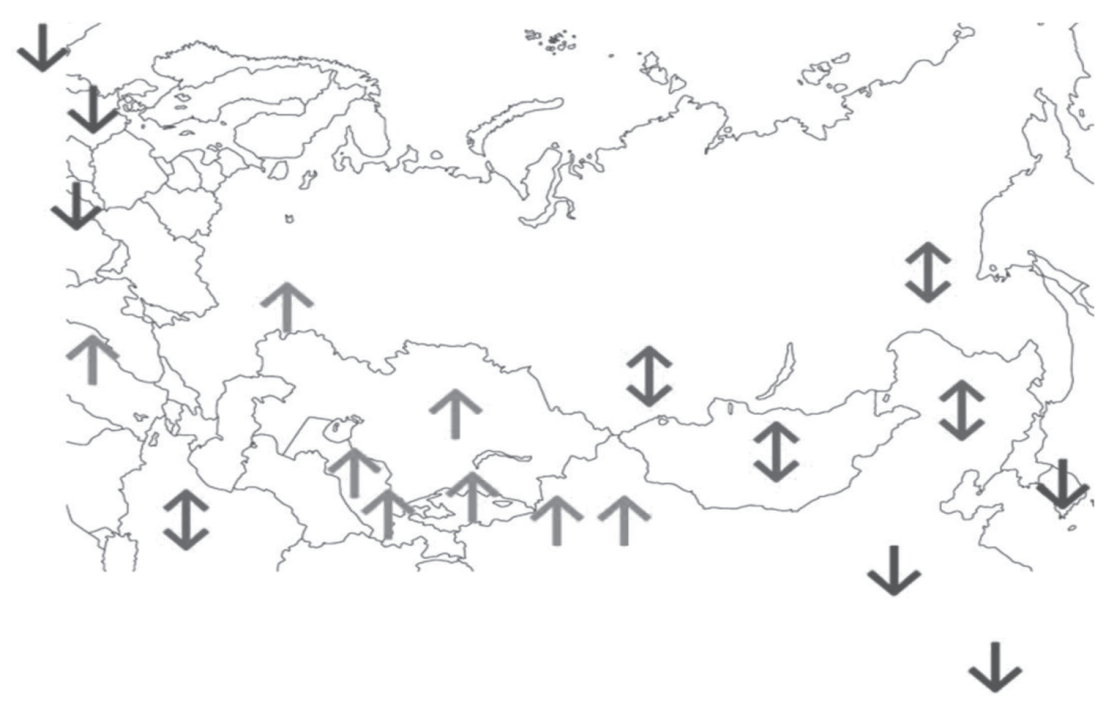

${ }^{6}$ DSRs in Kirghiz, which has been strongly influenced by Kazakh, utilize, among others, the vowel alternation pattern /w/-/u/ which is not evidently 'low-high' and which is foreign to DSRs in the Turkic languages listed in (2) and (3).

Kirghiz /tars turs,dzalt dzult, dzult dzult, kult kult/, etc.

(These are spelled жалт-жулт, жылт-жулт, and кылт-култ in Kirghiz orthography.) This might allow the speculation that Kirghiz DSRs, like Manchu and Mongolian DSRs, originally had no preference for the high-low or low-high order but is in the process of developing a 'Turkic-type' preference for the lowhigh order under the influence of Kazakh. (According to Golden (1998), in the ninth century, there was the 'Kirghiz' people 'whose primary habitat was in the Yenisey region' (Golden 1998: 21). The Kirghiz language of today also 'shares some features with South Siberian Turkic' (Kirchner 1998: 344).) 
In summary, this paper has introduced a new perspective from which to analyze sound symbolic reduplicatives, namely to contrast different languages with regard to vowel alternation patterns in their DSRs. It has also argued for the hypothesis that, synchronically speaking, the relative height of a vowel against the other in the DSR is a linguistic feature that is primarily areal.

\section{Address:}

Shinji Ido

1-15-28-1001 Marunouchi

Naka-ku

Nagoya

Japan

E-mail: shinji_ido@mail.aichi-fam-u.ac.jp

\section{References}

Golden, P. B. (1998) “The Turkic peoples: a historical sketch”. In The Turkic languages, 16-29. London: Routledge.

Kirchner, M. (1998) "Kirghiz”. In The Turkic languages, 344-356. London: Routledge.

Reay, I. E. (2006) "Sound symbolism". In Encyclopedia of language and linguistics. 2nd ed., 531-539. Maryland Heights: Elsevir.

\section{SOURCES OF LINGUISTIC DATA}

For English:

Reay, I. E. (2006) "Sound symbolism". In Encyclopedia of language and linguistics. 2nd ed., 531-539. Maryland Heights: Elsevir.

For German:

Satô, Yôko (1971) “Nihongo, doitsugo ni okeru onomatope ni tsuite”. Kôza nihongo kyôiku 7, 162-180.

For Kazakh:

Shadaeva, Madina (2003) "Kazafugo oyobi nihongo ni okeru giongo gitaigo no hikaku taishô". Nihongo kyôiku shidôsha yôsei puroguramu ronshû 2, 231-280.

For Tatar:

Tatar telenẽ̃ sarıfi (2008. Retrieved December, 2008, from web site: http://tugan tel.noka.ru/belem/sarif/09561 and http://tugan-tel.noka.ru/belem/sarif//09563 
For Tatar in China:

Chen, Zongzhen and Liqian Yi (1986) Tata'er yu jian zhi, 119-121. Beijing: Min zu chu ban she.

For Turkish:

Zülfikar, Hamza (1995) Türkçe ses yansımalı kelimeler. Ankara: Türk Dil Kurumu.

For Uyghur:

Baqi, Abdukerim (1983) Hazirqi zaman uyğur tili, 164-168. Beijing: Min zu chu ban she.

Tömür, Hämit (2003) Modern Uyghur grammar, 459-464. İstanbul: Yıldız Teknik Üniversitesi.

For Uzbek:

Kononov, A. N. (1960) Grammatika sovremennogo uzbekskogo literaturnogo jazyka, 339. Moscow, Leningrad: zdatel'stvo akademii nauk SSSR.

Hamroyev, M. A. (2004) O'zbek tilidan maruzalar to 'plami, 86. Tashkent: Nizomiy nomli Toshkent Davlat Pedagogika universiteti.

O'rinboyev, B. (1982). O'zbek so'zlashuv nutqi, 26-27. Tashkent: Fan.

Ko'ng urov, R. Q. (1975) "Taqlid so'z”. In G'. A. Abdurahmonov, Sh. Sh. Shoabdurahmonov, and A. P. Hojiev, eds. $O$ 'zbek tili grammatikasi. 1 tom: Morfologiya, 602-608. Toshkent: Fan.

For Uzbek in China:

Cheng, Shiliang and Abudureheman (1987) Wuzibieke yu jian zhi, 107-109. Beijing: Min zu chu ban she.

For Qarakhanid:

Ido, Shinji. (2008) "Divanü Lügat-it Türk’teki yansımalı kelimelerde ünlü nöbetleşmesi”. Akademik araştırmalar 39, 263-272.

For Manchu:

Kawachi, Yoshihiro (1996) Manshûgo bungo bunten, 159-161. Kyoto: University of Kyoto.

Yamamoto, Kengo (1969) Manshûgo kôgo kiso goishû. Tokyo: Institute for the Study of Languages and Cultures of Asia and Africa, Tokyo Univ. of Foreign Studies.

For Mongolian:

Hangin, Gombojab (1986) A modern Mongolian-English dictionary. Bloomington: Indiana University, Research Institute for Inner Asian Studies.

Ozawa, Shigeo (1978) Mongorugu no hanashi, 53-57. Tokyo: Daigaku shorin. Ozawa, Shigeo (1994) Gendai Mongorugo jiten. Tokyo: Daigaku shorin. 
For Tuvan:

Isxakov, F, G. and A. A. Pal'mbax (1961) Grammatika tuvinskogo jazyka. Moscow: Izdatel'stvo vostoènoj literatury.

For Bukahran Tajik:

A 21 year old subject.

For Persian:

Yoshie, Satoko (1992) “Onomatopoeia in Modern Persian”. Journal of Asian and African Studies 44, 95-117.

For Korean:

Aoyama, Hideo (1991) Chôsengo shôchôgo jiten. Tokyo: Daigaku Shorin.

Sohn, Ho-Min (1994) Korean, 518. London: Cambridge University Press.

For Chinese:

Noguchi, Munechika and Ch'ang-chiang Wang (1979) "Chûgokugo ni okeru giseigo goi no kenkyû”. Kumamoto daigaku kyôikugakubu kiyô 28, 11-19.

Noguchi, Munechika and Ch'ang-chiang Wang (1980) "Chûgokugo ni okeru giseigo goi no kenkyû (II)". Kumamoto daigaku kyôikugakubu kiyô 29, 9-15.

For Vietnamese:

Le, Van Cu (1989) “Betonamugo no giongo-gitaigo". Nihongo kyôiku 68, 131-135.

For Hungarian:

Kenesei, István, Robert M Vago, and Anna Fenyvesi (1998) Hungarian: descriptive grammar, 454. London and New York: Routledge.

For Kirghiz:

Koca, Ergün (2007). "Kırgız ve Türk Dillerindeki Yansıma Sözcüklerden Oluşan İkilemeler”. Kırgız Dili ve Edebiyatı Dergisi 12.

Kokkuvõte. Shinji Ido: Vokaalivaheldus kahesilbilistes reduplikatiivides: areaalne dimensioon. Käesolev artikkel analüüsib erinevaid keeli keskendudes vokaalivaheldusmustritele kahesilbilistes deskriptiivsetes reduplikatiivides. Analüüs näitab, et 1) mitmetel erinevatel keeltel on oma eelistatavad vokaalivaheldus mustrid nimetatud reduplikatiivide jaoks (nt ingl k/I/-/p/ vormides ding-dong ja tick-tock) ja 2) sellistel juhtudel on iga vokaali kõrgus võrreldes teisega niisugune keeleline nähtus, mis on eelkõige piirkondlik. Keeled, mida siinses uurimuses käsitletakse, on Bukhara tadžiki keel, hiina, inglise, saksa, kasahhi, korea, mandžu, mongoolia, pärsia, Kara-Khani turgi, tatari, tatari keel Xinjiangis, türgi, tuva, uiguuri, usbeki ja usbeki keel Xinjiangis.

Märksõnad: reduplikatsioon, häälikusümboolika, vokaalivaheldus, piirkondlikud nähtused 
